\title{
Pentingnya Manajemen Data Pengeboran untuk Analisis Data Dalam Meningkatkan Operasi Pengeboran Panas Bumi
}

\author{
Daniel Adityatama ${ }^{1}$, Rizky Mahardhika², Dorman Purba ${ }^{1,2}$, Farhan Muhammad ${ }^{1}$, \\ Riviani Kusumawardani ${ }^{1}$, Ribka Asokawaty ${ }^{1}$
}

\begin{abstract}
ABSTRAK
Pengeboran merupakan salah satu komponen biaya utama dalam eksplorasi dan pengembangan panas bumi. Pengeboran yang efektif dan hemat biaya berkontribusi signifikan terhadap keberhasilan pengembangan panas bumi. Faktor kunci dalam mengurangi biaya pengeboran adalah mengoptimalkan operasi, memanfaatkan tenaga kerja secara maksimal, dan juga melakukan benchmarking dengan aktivitas pengeboran lainnya untuk mengevaluasi kinerja seseorang secara objektif. Hal ini dimungkinkan jika informasi mengenai kegiatan pengeboran sebelumnya disimpan dan dengan mudah dikumpulkan dan dianalisis sebelum membuat rencana untuk kegiatan pengeboran.

Tujuan dari makalah ini adalah untuk merangkum definisi dan contoh pengelolaan data pengeboran pada industri yang lebih mapan seperti minyak dan gas dari berbagai penelitian di masa lalu, menilai keuntungan memiliki database pengeboran atau sistem pengelolaan data yang tepat, dan bagaimana data dapat digunakan untuk meningkatkan operasi pengeboran di masa mendatang. Sebuah studi kasus untuk mengubah data warisan dari kegiatan pengeboran sebelumnya dari dua lapangan panas bumi di Jawa menjadi database juga dibahas untuk menunjukkan bagaimana data pengeboran lama dapat digunakan untuk mengevaluasi kinerja pengeboran. Dari data pengeboran terdahulu dapat di analisis data rata-rata durasi pengeboran, time breakdown, analisis NPT, dan rata-rata ROP vs manufaktur.
\end{abstract}

Kata kunci: Pengeboran, manajemen data, analisis data, panas bumi

\section{ABSTRACT}

Drilling is one of the major cost components in geothermal exploration and development. Effective and cost-efficient drilling significantly contribute to the success of geothermal development. Key factors in reducing drilling costs are optimising operations, utilising manpower to its fullest potential, and also benchmarking with other drilling activities to evaluate one's performance objectively. This is possible if the information regarding the previous drilling activities is stored and easily gathered and analysed before making plans for the drilling campaign.

1 PT. Rigsis Energi Indonesia, Jakarta

2 PT. Enerka Bhumi Pratama, Jakarta 
The purpose of this paper is to summarise the definition and examples of drilling data management in a more well-established industry such as oil and gas from various studies in the past, assess the advantages of having a proper drilling database or data management system, and how can the data be used for potentially improving future drilling operation. A case study of converting legacy data from previous drilling campaign of two geothermal fields in Java into a database is also discussed to demonstrate how legacy drilling data can be used to evaluate drilling performance. From previous drilling data, it can be analyzed data on average drilling duration, time breakdown, NPT analysis, and average ROP vs manufacturer.

Keywords: Drilling, data management, data analysis, geothermal

\section{PENDAHULUAN}

\section{A. Pengembangan Panas Bumi Indonesia}

Rencana Umum Energi Nasional (RUEN) Indonesia menyatakan bahwa energi terbarukan harus mencapai 23\% dari total bauran energi Indonesia (Kementerian ESDM 2017), di mana sekitar 7.200 MW atau 16\% bersumber dari energi panas bumi (Umam, dkk., 2019). Dengan Kapasitas pembangkit listrik panas bumi terpasang sekitar $1.950 \mathrm{MW}$ pada akhir tahun 2018, peningkatan 5.000 MW dalam jangka waktu $\sim 6$ tahun merupakan target yang berani untuk sedikitnya (Purba, dkk. 2019). Salah satu penyebab lambatnya laju pengembangan ini adalah tingginya biaya di muka yang diperlukan selama eksplorasi, dengan pengeboran sebagai kontributor utama. Oleh karena itu, penting untuk menurunkan biaya per MW dengan memiliki biaya pengeboran per sumur yang dapat diterima. (GeothermEx, 2010, Purba., dkk. 2019).

Operasi pengeboran di panas bumi yang banyak ketidakpastiannya, membutuhkan banyak pengalaman sebelum mencapai kondisi yang paling optimal. Heterogenitas kondisi bawah permukaan dibandingkan minyak dan gas merupakan tantangan lain dalam pengeboran panas bumi, sehingga pembelajaran dari operasi pengeboran sebelumnya sangat berharga untuk memperbaiki keseluruhan perencanaan dan pengoperasian pengeboran. Namun, sebagian besar data pengeboran dari kegiatan pengeboran sebelumnya diabaikan, atau hanya disimpan di hard drive/ server perusahaan tanpa penataan yang tepat. Hal ini membuat analisis pengeboran menjadi sulit atau bahkan tidak mungkin dilakukan, karena drilling engineer harus menggali tumpukan folder dan file hanya untuk menemukan beberapa bagian informasi. Dalam industri minyak dan gas, kesadaran untuk memiliki database pengeboran dan sistem manajemen data yang tepat sudah dikenal luas dan telah menjadi topik populer selama bertahuntahun (Hanley, dkk., 2011, Iyoho, Meize, dkk., 2005, Shi, dkk., 2015, Sumbal, dkk., 2017).

Namun sejauh pengetahuan penulis akan pentingnya database pengeboran di panas bumi, apalagi sistem pengelolaan data pengeboran di Indonesia belum menjadi perhatian yang serius.

\section{B. Mengoptimalkan Operasi Pengeboran untuk Mengurangi Biaya Pengeboran}

Karena pengeboran merupakan salah satu kontributor terbesar dalam total biaya proyek panas bumi, maka optimalisasi perlu dilakukan Kegiatan pengeboran, terutama karena pengeboran memiliki risiko tinggi akibat ketidakpastian selama pengoperasian. Salah satu cara untuk mengoptimalkan perencanaan dan pelaksanaan pengeboran adalah denganr menganalisis operasi pengeboran sebelum- 
nya, atau dalam teknik pengeboran dikenal dengan analisis pengeboran (Gambar 1). Namun, (Iyoho, dkk., 2004), menegaskan bahwa analisis pengeboran tidak dilakukan secara rutin sebagaimana mestinya. Salah satu alasan utama mengapa analisis pengeboran tampaknya diabaikan adalah karena sebagian besar perusahaan tidak memiliki sistem pengelolaan data berbasis pengetahuan yang terorganisir yang dapat dengan baik menghubungkan silang parameter pengeboran dan geologi yang relevan.

Kekhawatiran lainnya adalah kurangnya retensi pengetahuan dalam industri minyak dan gas, khususnya pengeboran (Sumbal, dkk., 2017). Ada kesenjangan generasi antara drilling engineer, dan sangat penting untuk memiliki catatan pembelajaran dan proses yang tepat untuk memastikan transfer pengetahuan antara drilling engineer (Damski, 2014).
Penulis percaya bahwa jika di sektor mapan seperti minyak dan gas, kurangnya retensi pengetahuan terlihat, maka dapat diasumsikan bahwa hal itu akan sama di industri yang kurang mapan seperti panas bumi. Oleh karena itu, tanpa catatan pembelajaran yang tepat, deskripsi proses, pengetahuan lapangan, dan analisis pengeboran yang tepat dari data operasi pengeboran sebelumnya, akan sulit bahkan tidak mungkin untuk mengoptimalkan/ meningkatkan perencanaan pengeboran di masa mendatang.

Data yang dicatat dapat bervariasi dari laporan aktivitas harian, kinerja bit, survei log, data lumpur pengeboran, dll. Namun, lebih sering daripada tidak, data dan laporan pengeboran sebelumnya disimpan dalam berbagai format dan folder yang tidak konsisten. Ini mungkin menyebabkan masalah berikut:

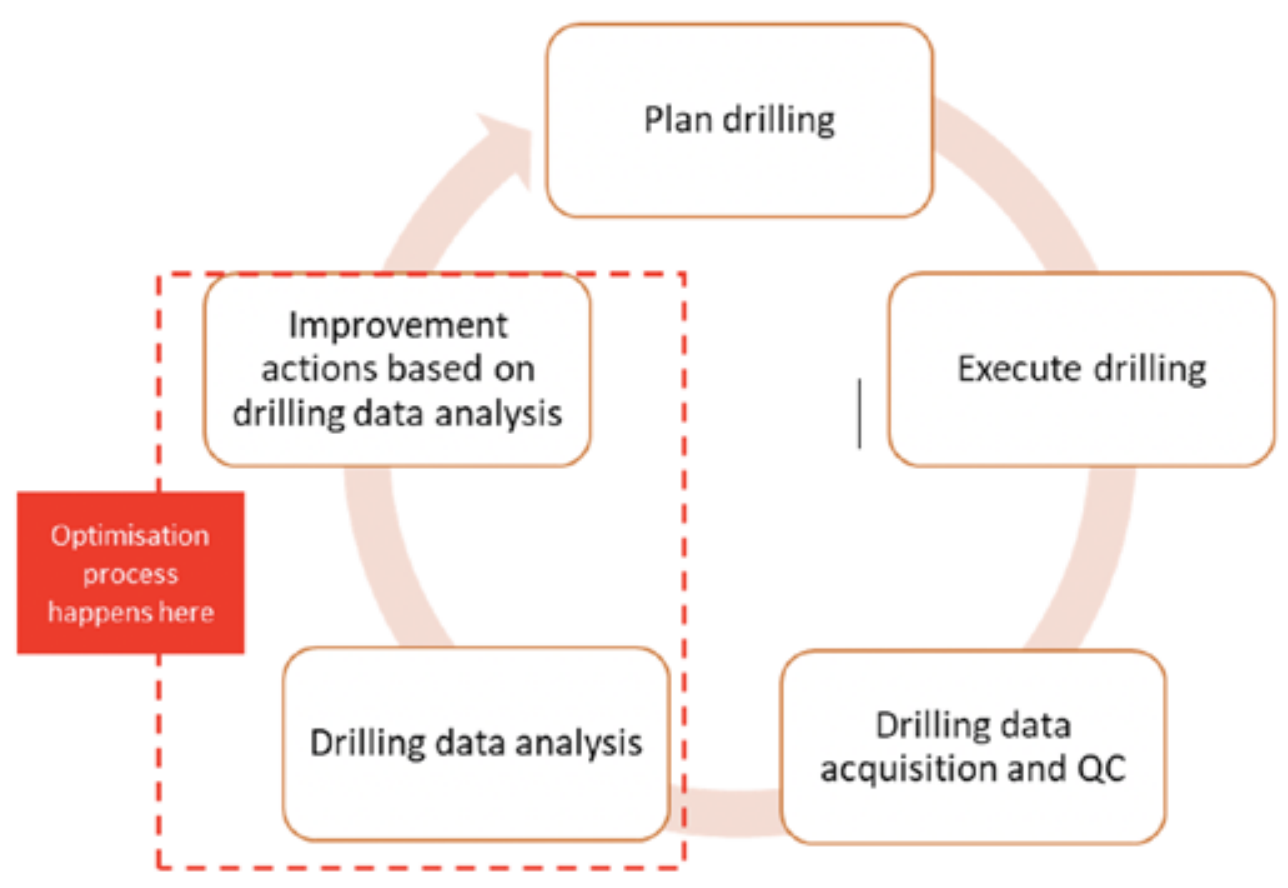

Gambar 1. Perencanaan dan Siklus Operasi Pengeboran

a. Engineers harus menggali secara manual ke dalam folder dan mengurutkan tumpukan data atau laporan untuk menemukan informasi yang mereka butuhkan. Ini memakan waktu, dan jika lokasi folder tidak konsisten, personel lain yang tidak mengetahui ketersediaan atau lokasi data akan kesulitan menemukan informasinya. 
b. Data/ laporan pengeboran yang ada mungkin memiliki format yang berbeda, sehingga sulit untuk dikumpulkan, dibandingkan, dan dianalisis.

\section{Tujuan Studi}

Seperti yang telah dibahas di bagian sebelumnya, mengoptimalkan pengeboran panas bumi tidak mungkin dilakukan tanpa belajar dari operasi pengeboran sebelumnya. Namun, pelajaran dan data dari kegiatan atau operasi sebelumnya sering diabaikan karena tidak ada database atau sistem manajemen data yang tepat yang pada gilirannya membuat insinyur enggan untuk mencari informasi atau data. Oleh karena itu, tujuan dari makalah ini adalah sebagai berikut:

a. Meringkas definisi dan konsep pengelolaan data pengeboran dari literatur dan studi sebelumnya

b. Menilai keuntungan potensial dari memiliki database pengeboran panas bumi atau sistem manajemen data yang tepat

c. Mengeksplorasi bagaimana data dari operasi pengeboran sebelumnya dapat digunakan untuk meningkatkan perencanaan pengeboran di masa depan;

d. Apa yang bisa dilakukan dengan legacy/ data pengeboran historis yang belum disimpan dengan baik

Review literatur mengenai pengeboran panas bumi saat ini di Indonesia, pengelolaan data pengeboran dasar, dan analisis pengeboran dari industri perminyakan telah dilakukan. Sebuah studi kasus dari lapangan panas bumi di Jawa Tengah yang telah dibor di masa lalu dan akan dibor untuk perluasan di masa mendatang juga diselidiki untuk menunjukkan bagaimana data warisan masih dapat digunakan untuk perencanaan pengeboran di masa mendatang (Gambar 2).

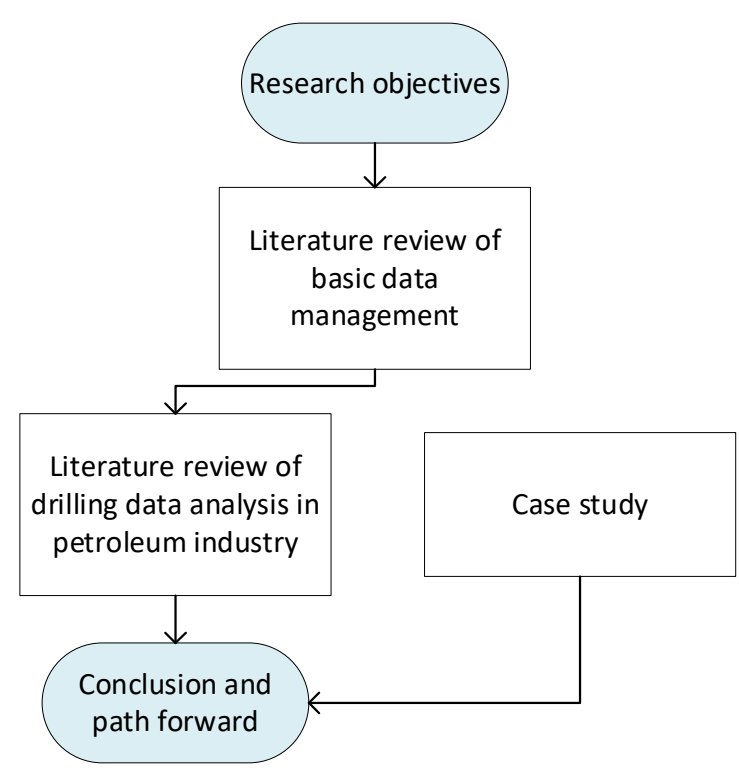

Gambar 2. Flowchart Metodologi Penelitian

\section{TINJAUAN PUSTAKA}

\section{A. Apa Itu Manajemen Data}

Pengertian data itu sendiri bermacam-macam tergantung pada sumber atau konteksnya, namun sederhananya dapat diartikan sebagai fakta, angka atau entitas lain yang tidak memiliki konteks atau tujuan tersendiri. Data harus diatur ke dalam konteks yang bermakna dan menjadi informasi. Informasi tersebut kemudian dapat diinterpretasikan, dianalisis, dan digunakan untuk berbagai keperluan seperti pengambilan keputusan, evaluasi, dll dan menjadi pengetahuan.

Oleh karena itu, data itu sendiri praktis tidak dapat digunakan kecuali diatur ke dalam $d a$ tabase atau dokumen.

Manajemen data dapat digambarkan sebagai "praktik mengumpulkan, menyimpan, dan menggunakan data secara efisien dan hemat biaya" (ORACLE 2019). 


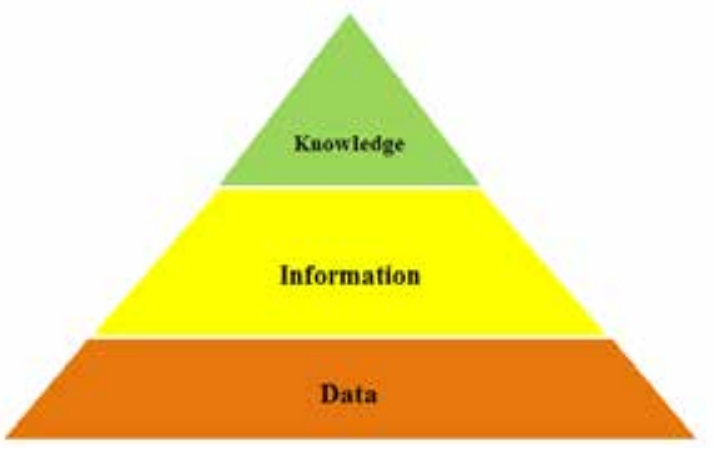

Gambar 3. Ilustrasi Data, Informasi, dan

Pengetahuan (dimodifikasi dari Damski, 2014)

Namun, istilah manajemen data dalam operasi pengeboran tidak jelas, karena terkadang mengalirkan data lumpur pengeboran secara real-time dari lokasi pengeboran ke kantor pusat atau mengumpulkan data (laporan, data lumpur pengeboran, data e-log, dll.) dan menyimpan di dalam hard drive atau server perusahaan dianggap cukup sebagai bentuk pengelolaan data. Damski (2014) menegaskan bahwa itu tidak cukup dalam arti bisnis, karena ini hanyalah biaya tanpa Return on Investment (ROI). Setelah informasi yang diekstrak dari data tersebut dapat digunakan untuk menghasilkan keputusan guna meningkatkan proses bisnis perusahaan, maka pengeluaran biaya untuk pengelolaan data akan menjadi masuk akal (Gambar 4). Pengumpulan atau perolehan dan penyimpanan data dari operasi pengeboran sebelumnya hanya akan menjadi biaya tambahan yang tidak ada nilainya jika data tersebut tidak dianalisis untuk menyampaikan business intelligence untuk meningkatkan proses bisnis (produktivitas, keselamatan, dll.) dari sebuah Perusahaan.

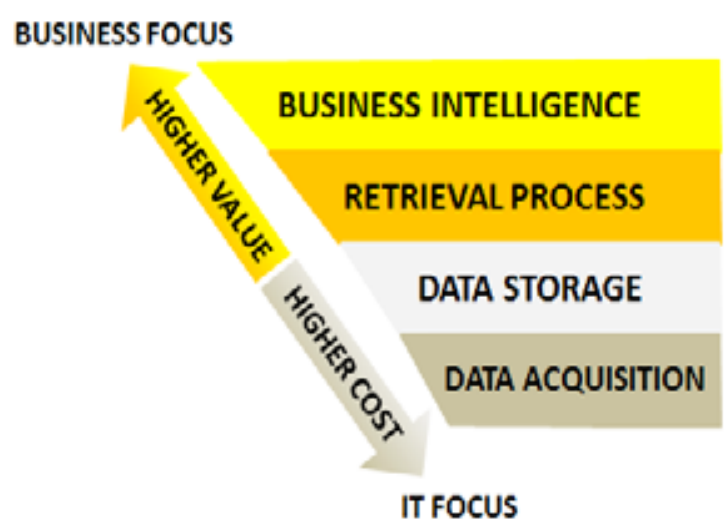

Gambar 4. Biaya vs Nilai Dalam Manajemen Data (dimodifikasi dari Damski, 2014)

Namun seperti yang telah dikemukakan pada bagian sebelumnya, bagian business intelligence hanya dapat dilakukan jika datanya tersedia dan mudah diakses atau diambil kembali. Dengan data yang tersedia dan diproses, perbedaan antara dua keputusan hanyalah masalah kecerdasan bisnis atau interpretasi data, yang pada gilirannya dapat memberikan program pengeboran yang lebih baik, perkiraan biaya pengeboran, dll.

\section{B. Manajemen Data Dalam Pengeboran}

Manajemen Data dalam Pengeboran Damski (2014) menjelaskan bahwa untuk operasi pengeboran, proses pengelolaan data dapat diringkas menjadi langkah-langkah sebagai berikut (Gambar 9):

- Data Acquisition

- Data QC

- Data Storage

- Data Retrieval

- Data Analysis

\section{Akuisisi Data}

Secara umum, ada dua jenis sumber data dalam pengeboran; satu adalah laporan yang diisi secara manual dan yang lainnya adalah 
laporan otomatis dari sensor seperti unit lumpur pengeboran. Laporan manual mungkin berkisar dari rapat pagi, daily drilling report (DDR) dalam bentuk file spreadsheet atau beberapa perangkat lunak canggih seperti $\mathrm{Pe}$ loton's WellView ${ }^{\mathrm{TM}}$, Halliburton's OpenWells ${ }^{\circledR}$, dll. $^{1}$

Di sisi lain, data elektronik dari sensor dikumpulkan secara real-time dan mungkin atau mungkin tidak langsung dikirim ke kantor untuk disimpan dan dibuat plot. Untuk kedua tipe data ini, keandalan data sangat penting. Hal ini membuat kendali mutu data menjadi penting dan akan dibahas pada bagian selanjutnya.

\section{Penyimpanan Data}

Penyimpanan data dalam pengeboran merupakan topik yang sangat menarik. Sejauh yang penulis ketahui, banyak perusahaan panas bumi menyimpan data atau laporan pengeboran dalam folder di dalam server atau komputer mereka. Namun, dalam perspektif IT, data seperti laporan, presentasi, gambar, bahkan file excel dianggap sebagai data "tidak terstruktur", karena tidak disimpan secara terstruktur dan seringkali memiliki format yang berbeda dan tidak konsisten, sehingga mempersulit untuk menyimpan dan mengambil (Gambar 5).

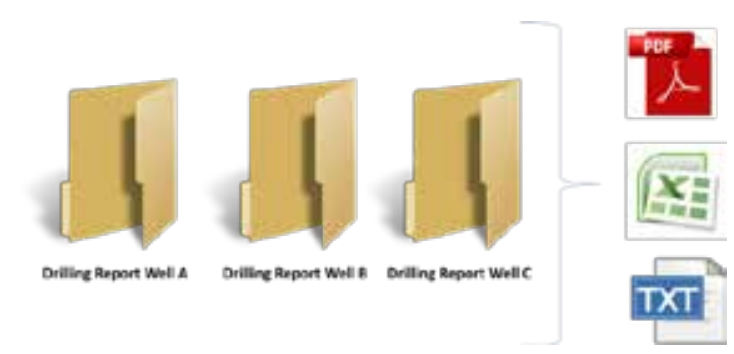

Gambar 5. Ilustrasi Penyimpanan Data Umumnya di Perusahaan

1 Terlepas dari metodenya, laporan manual melibatkan seseorang di rig untuk mengetik atau mengisi bentuk. Ini juga terjadi untuk catatan data lain seperti geologi, bit, biaya, fluida pengeboran, dll.
Database, di sisi lain, dianggap sebagai data "terstruktur", karena memiliki metode formal untuk mengatur dan mengambil data (Damski 2014).

Untuk mengatasi hal ini, perusahaan dapat memperoleh sistem database yang mengubah informasi di dalam file mereka menjadi database seperti yang disediakan oleh ORACLE, MySQL, dll. Untuk mengakses atau mengambil data, pengguna atau teknisi dapat menggunakan SQL (Structured Query Language) atau menggunakan antarmuka atau aplikasi grafis.

\section{Data QC}

Proses QA/ QC data sangat penting karena setiap data yang buruk (tidak konsisten atau bahkan salah) juga akan digunakan untuk analisis. Ada pepatah terkenal di dunia IT "sampah masuk - sampah keluar"; di mana masukan yang salah atau berkualitas buruk akan menghasilkan keluaran atau sampah yang tidak masuk akal. Seperti yang dinyatakan di bagian Akuisisi Data, kualitas laporan manual sangat bergantung pada orang di lokasi rig.

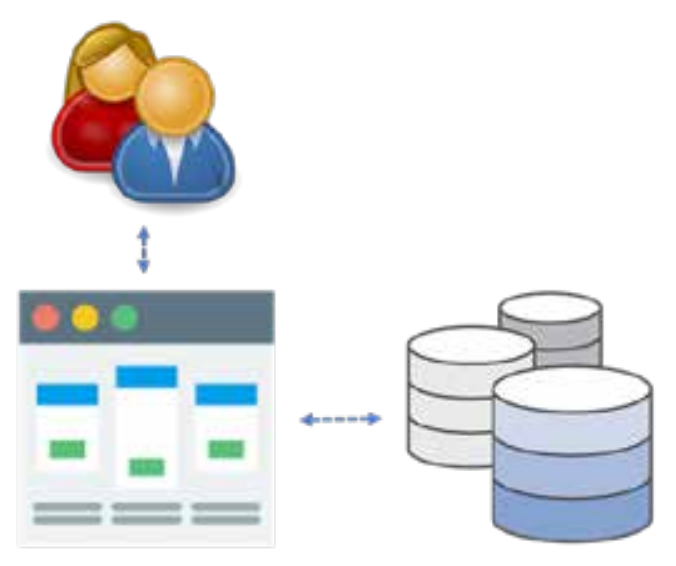

Gambar 6. Konsep yang disederhanakan tentang bagaimana pengguna mengakses data dalam database melalui antarmuka/ aplikasi

Ini lebih rumit daripada kedengarannya karena biasanya orang yang mengisi laporan 
manual (orang perusahaan atau supervisor pengeboran) harus mengawasi operasi, dan di akhir shiftnya dia harus membuat laporan. Jika supervisor pengeboran tidak mengetahui penggunaan data dari laporannya, ia dapat melewatkan atau melewatkan beberapa informasi yang menurutnya tidak penting. Sekalipun supervisor pengeboran mengetahui atau telah diberi pengarahan sebelumnya tentang apa yang harus dimasukkan dalam laporan, berdasarkan pengalaman penulis, banyak kejadian ketika beberapa detail terlewat dalam laporan hanya karena supervisor pengeboran terlalu sibuk dalam mengawasi operasi, dan pelaporan hanya menjadi renungan. Hal serupa dalam laporan otomatis (berbasis sensor), sensor yang salah atau tidak terkalibrasi akan memberikan pembacaan yang salah. Secara keseluruhan, Damski (2014) menjelaskan bahwa kesalahan yang paling sering terjadi pada database pengeboran adalah sebagai berikut:

- Datum/ unit salah

- Ketidakkonsistenan (misalnya seorang engineer dapat membuat kode satu operasi tertentu di satu sumur dan kode lain dalam operasi yang sama di sumur yang berbeda, membuat perbandingan menjadi sulit).

- Sumber data tersebar

- Anomali

- Hubungan buruk antara entitas data

Proses QC sering diabaikan oleh orang-orang meskipun ini sangat signifikan pengaruhnya. Mendapatkan data relatif mudah, tetapi tanpa QA/ QC yang tepat, hasil analisis bisa saja tidak tepat atau menyesatkan.

\section{Pengambilan Data}

Setelah data disimpan di beberapa database, tugas berikut adalah cara mengambilnya dengan mudah. Dalam data tidak terstruktur seperti laporan, presentasi, dan gambar yang disimpan dalam folder, mengambil data bukanlah tugas yang mudah. Dalam sebuah database dapat dilakukan dengan menggunakan bahasa yang disebut dengan Standard Query Language (SQL). Namun, SQL sendiri terkadang tampak seperti domain untuk Engineer IT, dan tampak seperti tanah asing bagi drilling enginer. Oleh karena itu untuk menyederhanakan banyak hal bagi pengguna, penting untuk memiliki antarmuka grafis untuk melakukan kueri atau mengambil data yang diperlukan.

Analisis data dapat digambarkan sebagai "metode untuk memeriksa, mengubah dan memodelkan data yang bertujuan untuk mendeteksi pola, mengembangkan penjelasan, menguji hipotesis, menyoroti informasi yang berguna, menyarankan kesimpulan dan mendukung pengambilan keputusan" (Damski 2014, Iyoho, Millheim, dkk., 2004). Tujuan utama dari seluruh manajemen data (dan analisis data khususnya) adalah bagaimana hal ini akan menguntungkan atau meningkatkan keseluruhan bisnis. Analisis data pengeboran dapat digunakan untuk merefleksikan kondisi di masa lalu, sekarang, dan masa depan (Gambar 10). Dalam operasi pengeboran sehari-hari, perusahaan akan membutuhkan ketiganya. Masa lalu dapat digunakan sebagai dasar sejarah untuk memahami kinerja masa lalu, untuk merencanakan sumur di masa depan, dan untuk meramalkan potensi masalah. Ini juga membantu untuk membantu pengambilan keputusan dalam kondisi saat ini, terutama jika masalah yang muncul telah terjadi di masa lalu. 


\section{Menganalisis Data Pengeboran}

\section{Proses Pengeboran}

Seperti yang telah dikemukakan pada bagian sebelumnya, data pengeboran (baik di masa lalu maupun saat ini) sangat penting dalam setiap tahapan siklus hidup sumur. Salah satu pendekatan untuk manajemen kualitas dan peningkatan berkelanjutan adalah siklus PDCA (Plan, Do, Check, Act) (Johnson 2002, Sokovic, Pavletic dan Pipan 2010). (Gambar 1) mengilustrasikan siklus pengeboran sumur, dan itu menyerupai siklus PDCA. Tanpa database pengeboran yang baik, setiap tahapan siklus hidup sumur akan terganggu. Tidak akan ada data, informasi, dan pembelajaran dari operasi pengeboran sebelumnya untuk membantu penyempurnaan rencana pengeboran berikutnya.

Tahap eksekusi juga akan terganggu, karena setiap masalah yang dihadapi selama operasi akan menjadi masalah baru, karena tidak ada catatan tentang masalah di masa lalu dan bagaimana cara mengatasi atau menguranginya. Peningkatan dan pemanfaatan yang mungkin dari analisis data pengeboran dibahas di bagian selanjutnya.

Data pengeboran sangat penting dalam tahap perencanaan dan evaluasi operasi pengeboran. Engineer dapat menggunakan data historis (setelah dikumpulkan, diatur, dan dikontrol kualitasnya) untuk mengidentifikasi apa dan di mana masalah yang dihadapi di masa lalu, apa dan di mana perbaikan dapat dilakukan dalam perencanaan masa depan. Ada beberapa alat untuk meningkatkan perencanaan pengeboran melalui analisis data historis (Damski 2014):

- Analisis waktu produktif

- Analisis pengendalian proses

- Analisis non-produktif (NPT)

- Analisis Best Composite Time (BCT) dan Technical Limit
- Analisis kinerja bit

- Learning Curve Analysis

- Analisis Benchmark

Dalam industri minyak dan gas, beberapa pekerjaan telah dilakukan untuk mengusulkan metodologi analisis pengeboran. Salah satunya adalah "10 langkah metodologi" yang dikemukakan oleh Iyoho, dkk.,. (2004). Langkah-langkahnya adalah sebagai berikut:

- Define Project objectives and scope. Untuk memahami konteks, target, dan merancang rencana. Tahapan ini seharusnya memberikan jawaban atas pertanyaanpertanyaan berikut: dimana kita sekarang? Dimana kita ingin berada? Apa yang mungkin? Bagaimana kita bisa sampai di sana?

- Data selection and QA/ QC. Kumpulan data yang sebanding diidentifikasi, dikumpulkan, dan diperiksa integritasnya sebelum analisis selanjutnya.

- Best Composite Time (BCT). Waktu terbaik yang dicatat untuk setiap aktivitas sekuensial yang bijaksana (rig up, make up bit, run in hole, dll.) Dari data sumur yang sebanding diidentifikasi dan ditambahkan untuk membuat waktu pengeboran "sumur ideal". Kemudian BCT ini dapat digunakan untuk perencanaan pengeboran di masa depan. Perhatikan bahwa BCT bukanlah batasan teknis dalam hal apa yang mungkin dilakukan, dalam hal apa yang telah dilakukan.

- Best Composite Cost (BCC). Setelah BCT diidentifikasi, kemudian diubah dengan total biaya untuk menganalisis target keuangan dengan lebih baik.

- Learning Curve-Analysis. Langkah ini dilakukan untuk menganalisis kinerja, kemajuan dan pencapaian secara umum dan di area spesifik pengeboran.

- Major Operations Analysis. Pada langkah 
ini, analisis waktu kerusakan dilakukan untuk operasi utama dan fase pengeboran untuk mengidentifikasi NPT dan masalah selama pengeboran.

- Detailed Problem Analysis and Opportunity Identification. Langkah ini mengevaluasi durasi waktu masalah dan kejadian/ pengulangan, sehingga pada gilirannya dapat mengidentifikasi area untuk perbaikan.

- Peer Review, Design Changes, and Technology Scouting. Peer review dilakukan untuk mempelajari kemungkinan optimalisasi proses pengeboran melalui perubahan desain, adopsi teknologi baru, dll.

- Economic Benefit Evaluation. Opsi perbaikan yang mungkin dari langkah 8 dinilai untuk solusi yang paling hemat biaya.

- Recommendation and Follow-up. Hasil dari langkah 9 diubah menjadi serangkaian rekomendasi dan mengukur dampak finansial yang diimplementasikan untuk terus meningkatkan BCT dan BCC.

\section{Proses Pengeboran}

Laporan pengeboran, baik laporan pengeboran harian yang dimasukkan secara manual dan lumpur pengeboran atau data berbasis sensor lainnya adalah bagian penting untuk memahami operasi pengeboran dan menganalisisnya. Namun, seringkali laporan harian hanya digunakan untuk rapat harian pagi, dan "dibuang" jika tidak ada masalah yang terlihat selama operasi. Dengan munculnya sistem manajemen data pengeboran yang tepat dan perangkat $\mathrm{BI}$, orang-orang mulai menyadari pentingnya data historis ini.

Namun, bahkan jika perusahaan menyadari pentingnya data historis ini dan dengan bantuan perangkat lunak pelaporan aktivitas yang canggih, terkadang masih sulit untuk memanfaatkan informasi secara akurat. Salah satu penyebab utamanya adalah pelaporan data kegiatan yang tidak tepat dan kurangnya proses pengkodean kegiatan operasional. (Nakagawa, Damski dan Miura 2005). Beberapa penelitian di masa lalu telah mencoba untuk mengidentifikasi apa saja hambatan yang menghalangi penggunaan data historis dan bagaimana menguranginya (Nakagawa, Damski dan Miura 2005, Damski 2014).

\begin{tabular}{|c|c|c|}
\hline Objectives & Barriers & Solutions \\
\hline $\begin{array}{l}\text { - Knowledge } \\
\text { retention } \\
\text { - Faster learning } \\
\text { - Operational } \\
\text { performance } \\
\text { improvement } \\
\text { - Cost reduction } \\
\text { - Risk estimation } \\
\text { - Uncertainties } \\
\text { estimation }\end{array}$ & $\begin{array}{l}\text { - Proper data } \\
\text { collection } \\
\text { - Data coding } \\
\text { process } \\
\text { - Database } \\
\text { replication } \\
\text { - Data } \\
\text { accessibility } \\
\text { - Data relevancy }\end{array}$ & $\begin{array}{l}\text { - Data input } \\
\text { quality control } \\
\text { process } \\
\text { - Shifting activity } \\
\text { coding process } \\
\text { to the planning } \\
\text { group instead of } \\
\text { operation } \\
\text { - Activity } \\
\text { reporting based } \\
\text { on planning } \\
\text { - Consolidated } \\
\text { information }\end{array}$ \\
\hline
\end{tabular}

Gambar 7. Hambatan dan solusi potensial untuk memanfaatkan sepenuhnya data riwayat aktivitas pengeboran (dimodifikasi dari Nakagawa et al., 2005)

Dapat dilihat bahwa proses pengkodean sangat penting untuk analisis data historis, namun karena tidak terstandardisasi dalam industri panas bumi di Indonesia, hal ini dapat menyebabkan beberapa ketidakakuratan karena beberapa alasan berikut:

- Tidak cukup detail untuk membedakan aktivitas yang berbeda, atau terlalu detail sehingga membuat orang yang membuat laporan mengidentifikasi kode yang tepat;

- Pengkodean yang tidak konsisten karena orang yang berbeda memasukkan laporan aktivitas; 
- Perbedaan kapan harus memulai atau mengakhiri kode aktivitas dalam pelaporan;

- Pengkodean yang tidak konsisten untuk waktu bermasalah.

Oleh karena itu, untuk pelaporan aktivitas pengeboran yang tepat, perusahaan harus membentuk tim yang berdedikasi untuk menilai sistem kode aktivitas mereka, menetapkan standar, melaksanakan pelatihan, dan mensosialisasikan pentingnya laporan aktivitas pengeboran yang tepat ke seluruh organisasi.

\section{STUDI KASUS}

\section{A. Permasalahan}

Sebuah perusahaan panas bumi di Indonesia tidak memiliki database operasi pengeboran sebelumnya. Data lama yang tersedia hanyalah laporan dalam berbagai format (kebanyakan spreadsheet, dan berupa laporan pengeboran harian tunggal tanpa ringkasan). Masalah muncul ketika perusahaan ingin melakukan kegiatan pengeboran berikutnya untuk perluasan pembangkit listrik. Laporan yang tidak konsisten dan tidak terstruktur membuat analisis kinerja pengeboran menjadi sangat sulit.

\section{B. Solusi}

Manajemen data awal kemudian dilakukan untuk mengatur, QC data dan pembersihan, dan menerapkan sistem untuk mengubah laporan spreadsheet menjadi satu database historis terintegrasi. (Gambar 12) menunjukkan contoh laporan pengeboran harian, survei terarah, dan kinerja bit. Perhatikan bahwa semua laporan belum diringkas sebelum penerapan manajemen data. (Gambar 13) menunjukkan diagram alur pengelolaan data untuk data lama perusahaan.

\section{Implementasi dan Tantangan}

Pengelolaan data dimulai dengan memilah dan mengatur laporan, pemeriksaan kualitas data, membuat format tunggal untuk setiap jenis laporan, dan membangun sistem pengkodean aktivitas yang seragam. Namun, karena pengeboran dilakukan pada tahun 1998 dan tim pengeboran semula tidak ada lagi di perusahaan, beberapa tantangan terkait keandalan data dihadapi selama proses tersebut. Tantangan tersebut dijelaskan dalam (Gambar 8):
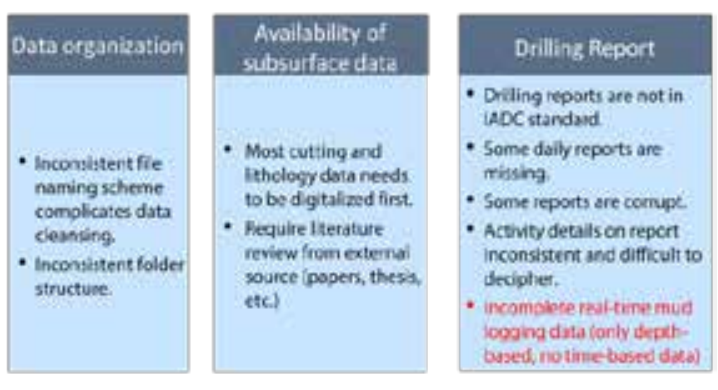

Gambar 8. Tantangan yang dihadapi selama proses pengelolaan data

Analisis data pengeboran dasar dapat dilakukan dengan alat BI seperti Microsoft Power BI atau Sisense, tetapi untuk penyiapan cepat dan alat yang tersedia di perusahaan, Microsoft Excel dapat digunakan. Beberapa contoh informasi yang diekstraksi setelah proses pengelolaan data ditunjukkan pada (Gambar 14). Perhatikan bahwa secara praktis tidak mungkin dilakukan tanpa pembersihan data dan menetapkan proses pengkodean aktivitas yang seragam terlebih dahulu.

\section{Hasil dan Pembelajaran}

Penerapan manajemen data menunjukkan bahwa tumpukan data yang tampaknya tidak mungkin digunakan dapat dimanfaatkan untuk mengekstrak informasi yang berguna untuk membantu kegiatan pengeboran di masa mendatang. Formatnya terbukti relatif 
mudah digunakan dengan perangkat lunak run-of-the-mill seperti Microsoft Excel. Namun, untuk mendapatkan manfaat penuh dari seluruh proses pengelolaan data di masa mendatang, beberapa poin perbaikan diidentifikasi:

- Gunakan proses Business Intelligence yang sesuai dengan tujuan untuk mengekstrak informasi penting yang diperlukan untuk pengambilan keputusan kegiatan pengeboran di masa mendatang.

- Menilai kode kegiatan untuk memastikan sudah sesuai dengan kebutuhan perusahaan.

- Memanfaatkan perangkat lunak pelaporan aktivitas pengeboran, atau buat spreadsheet laporan pengeboran harian standar (mengadopsi IADC atau standar lainnya) untuk memudahkan input laporan pengeboran ke database.

- $\quad$ QA/ QC semua laporan pengeboran sebelumnya segera dimasukkan ke database untuk memastikan akurasi dan keandalan.

\section{KESIMPULAN}

Studi ini telah merangkum konsep pengelolaan data pengeboran dan keuntungan dari berbagai sumber, sebagian besar dari industri yang lebih mapan seperti minyak dan gas. Dari studi pustaka dan studi kasus diperoleh beberapa poin:

- Penting untuk memiliki data pengeboran yang tepat \& terstruktur dalam bentuk database.

- Database yang tepat dapat dikembangkan lebih lanjut menjadi Manajemen Data Pengeboran yang lengkap.

- Pengelolaan Data Pengeboran yang baik akan sangat membantu dalam melakukan analisis data pengeboran dan business intelligence untuk meningkatkan proses bisnis. Tanpa itu, seluruh pengelolaan data hanya akan menjadi biaya tambahan yang tidak ada nilainya bagi perusahaan.

- Data pengeboran terdahulu masih dapat digunakan untuk menganalisis kinerja masa lalu dan memperoleh pembelajaran, tetapi membutuhkan banyak kontrol kualitas pasca pengeboran. Oleh karena itu disarankan untuk menerapkan proses pengendalian kualitas yang tepat dari tahap awal pengelolaan data pengeboran.

\section{DAFTAR PUSTAKA}

Damski, Carlos. 2014. Drilling Data Vortex: Where the bits meet the bits. Australia: Genesis Publishing and Services Pty Ltd.

GeothermEx. 2010. An Assessment of Geothermal Resource Risks in Indonesia. Working Paper, Richmond, California: GeothermEx, Inc.

Hanley, C., J. Kubicki, M. Lumpkin, and L. Tompkins. 2011. "Development of a Global Drilling Performance Database." SPE/IADC Middle East Drilling Technology Conference and Exhibition. Muscat, Oman: SPE International.

Iyoho, A. W., K. K. Millheim, B. K. Virginillo, A. R. Adeleye, and M. J. Crumrine. 2004. "Methodology and Benefits of a Drilling Analysis Paradigm." IADC/SPE Drilling Conference 2004. Dallas, Texas: SPE International. 
Iyoho, A. W., R. A. Meize, K. K. Millheim, and M. J. Crumrine. 2005. "Lessons from Integrated Analysis of GOM Drilling Performance." Offshore Technology Conference 200. Houston: SPE International.

Johnson, C. N. 2002. “The benefits of PDCA." Quality Progress (Proquest) 35 (5). https:// search.proquest.com/openview/6fb24b731a9c0c8bafd90096fd751e76/1?pqorigsite $=$ gscholar $\& \mathrm{cbl}=34671$.

Kementerian ESDM. 2017. "Rencana Umum Energi Nasional." Kementerian Energi dan Sumber Daya Mineral Republik Indonesia. Accessed June 2, 2019. https://www.esdm.go.id/id/ publikasi/ruen.

Nakagawa, E., C. Damski, and K. Miura. 2005. "What is the Source of Drilling and Completion Data?" Asia Pacific Oil \& Gas Conference and Exhibition. Jakarta: SPE International.

ORACLE. 2019. “What is Data Management?” ORACLE. Accessed June 5, 2019. https://www. oracle.com/database/what-is-data-management/.

Purba, D. P., D. W. Adityatama, M. F. Umam, and F. Muhammad. 2019. "Key Considerations in Developing Strategy for Geothermal Exploration Drilling Project in Indonesia." PROCEEDINGS, 44th Workshop on Geothermal Reservoir Engineering. Stanford: Stanford University.

Shi, X., Y. Zhou, P. Song, Q. Zhao, H. Jiang, Z. Huo, G. Yang, and X. Zhai. 2015. "Integrated Drilling Database Enables Automated Drilling Engineering Design." SPE/IATMI Asia Pacific Oil \& Gas Conference and Exhibition. Nusa Dua, Bali: SPE International.

Sokovic, M., D. Pavletic, and K. K. Pipan. 2010. "Quality Improvement Methodologies - PDCA Cycle, RADAR Matrix, DMAIC and DFSS." Journal of Acheivements in Materials and MAnufacturing Engineering (International OCSCO World Press) 43 (1).

Sumbal, M. S., E. Tsui, E. See-to, and A. Barendrecht. 2017. "Knowledge retention and aging workforce in the oil and gas industry: a multi perspective study." Journal of Knowledge Management (Emerald) 21 (4): 907-924. doi:10.1108/JKM-07-2016-0281.

Umam, M. F., J. Susilo, D. P. Purba, and D. W. Adityatama. 2019. “Design of Geothermal Drilling Training Curriculum as the Implementation of the National Competence Standard on Onshore Drilling." PROCEEDINGS, 8th ITB International Geothermal Workshop 2019. Bandung: Institut Teknologi Bandung. 


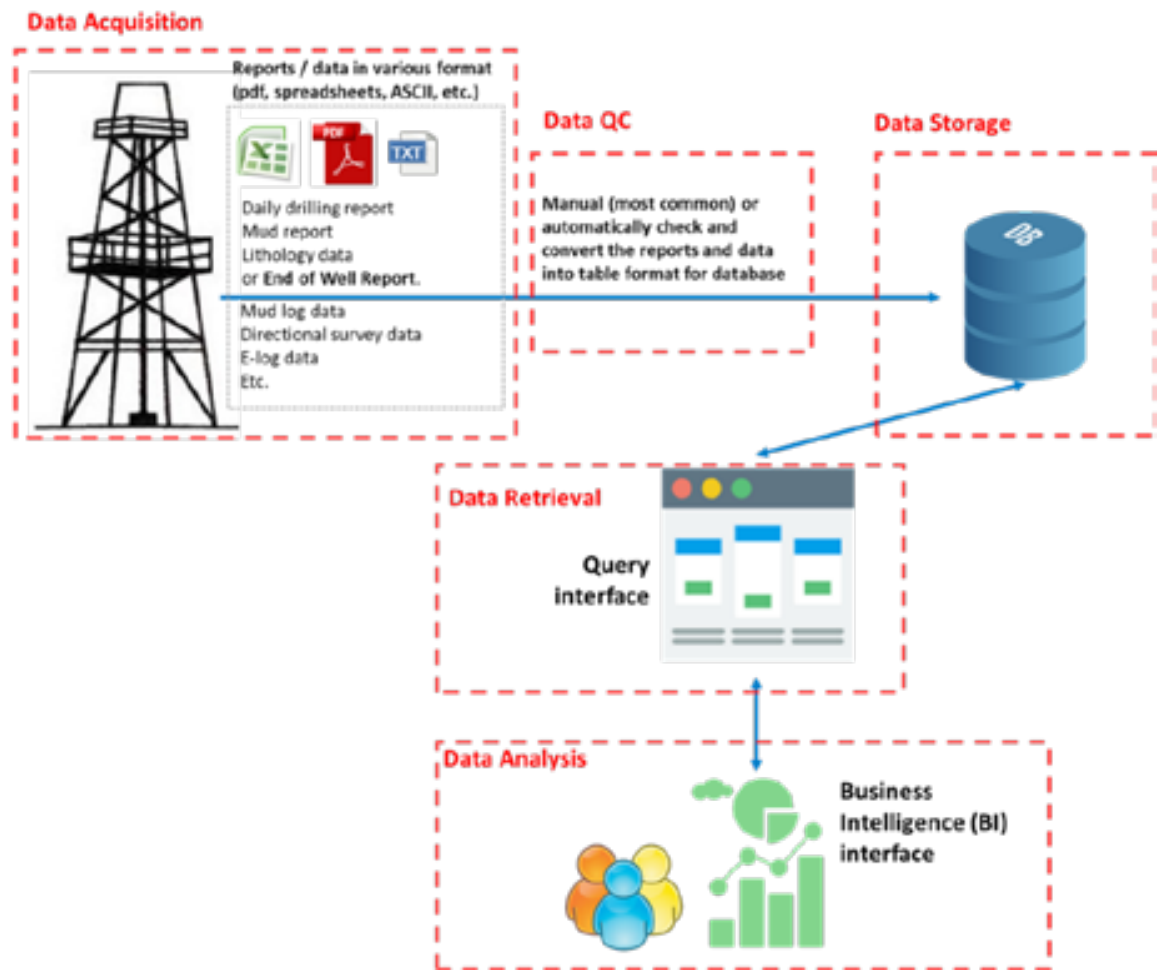

Gambar 9. Langkah-langkah pengelolaan data pengeboran. Dimodifikasi dari Damski (2014)

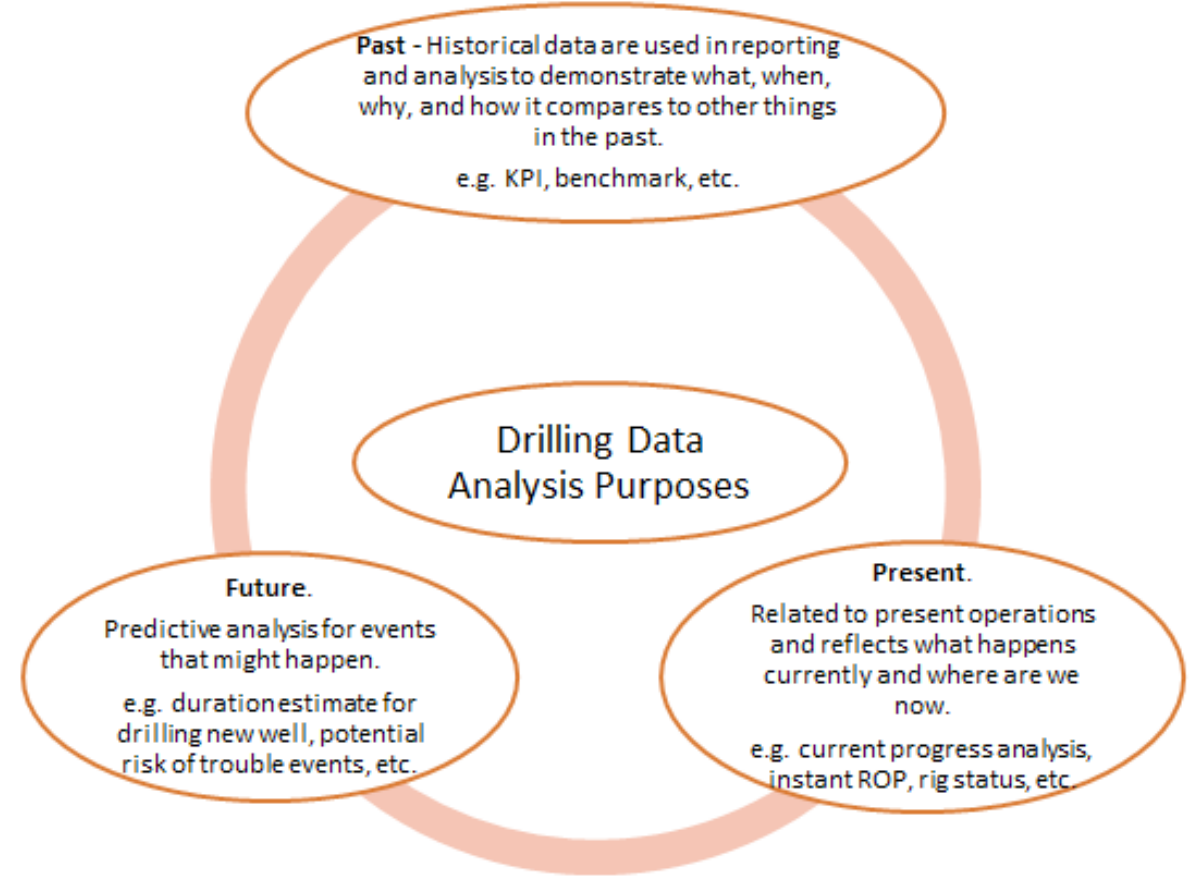

Gambar 10. Tujuan dasar analisis data pengeboran 


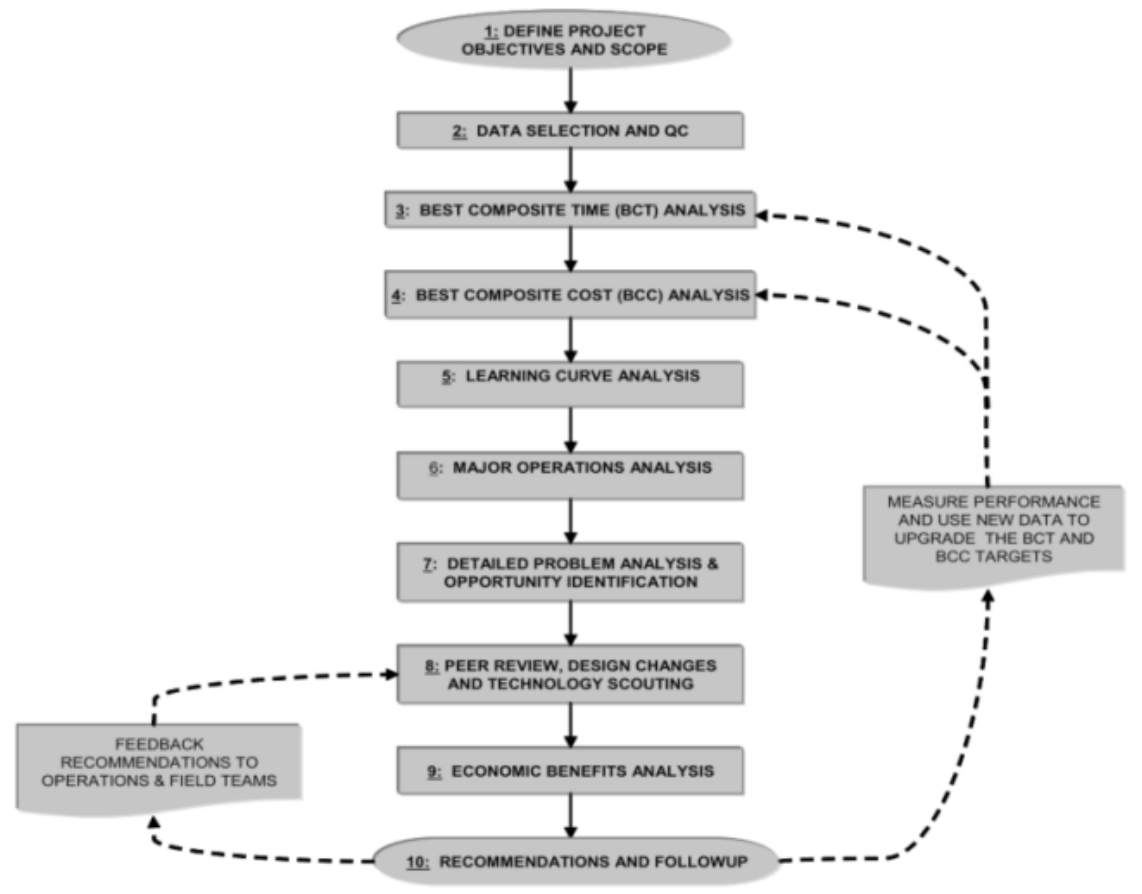

Gambar 11. 10 steps drilling analysis flowchart (Iyoho, Millheim, et al. 2004)

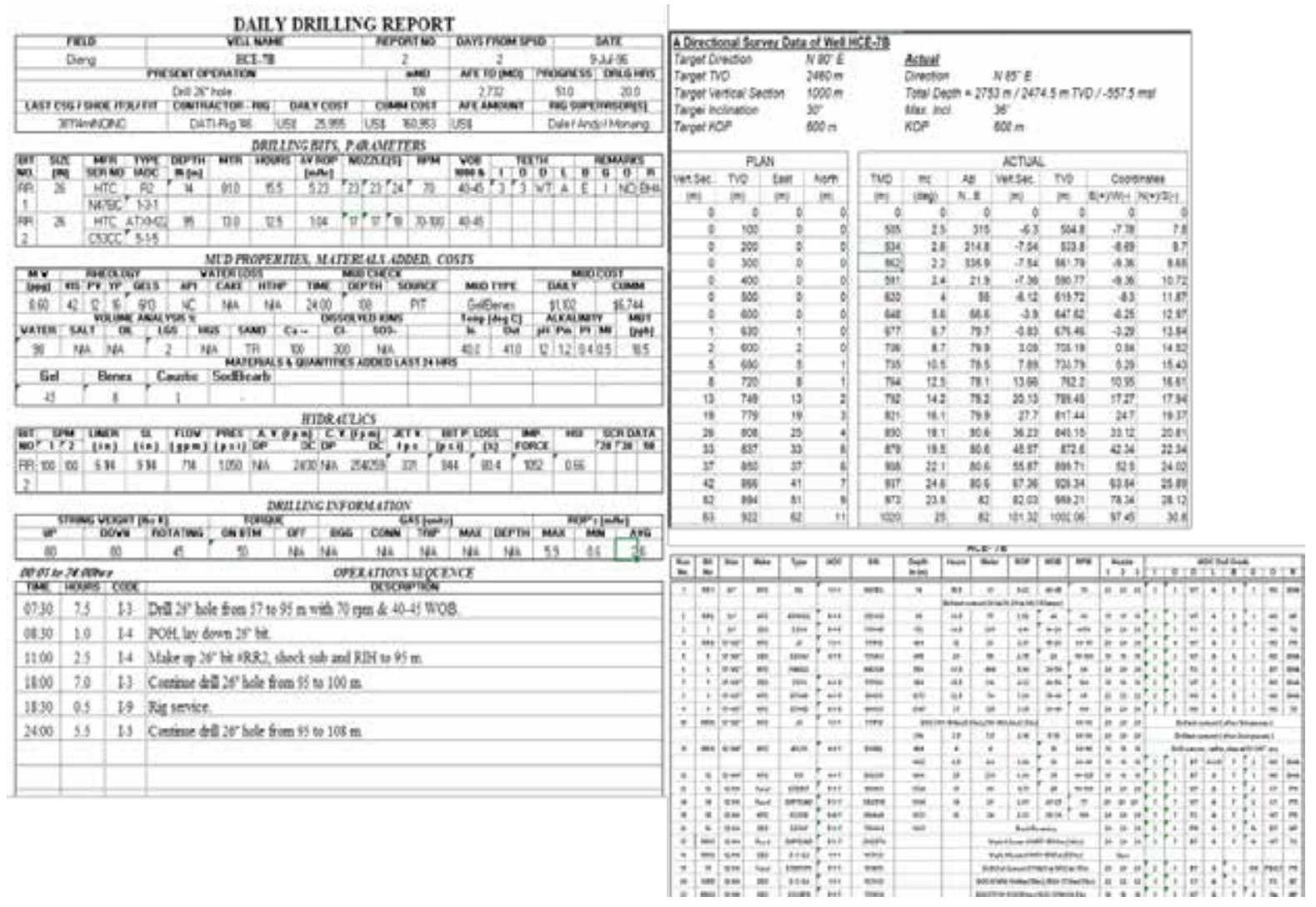

Gambar 12. Contoh laporan pengeboran lama (laporan pengeboran harian, survei, dan kinerja bit) 


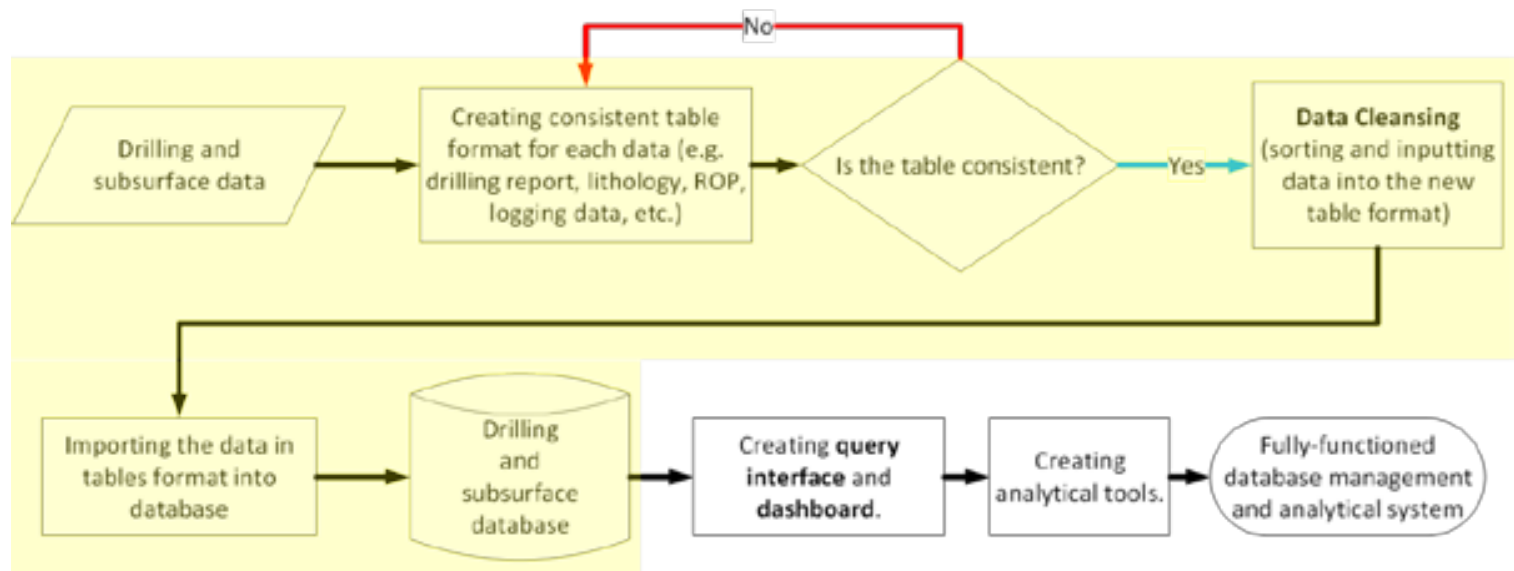

Gambar 13. Diagram alir manajemen data. Kemajuan saat ini disorot dengan warna kuning

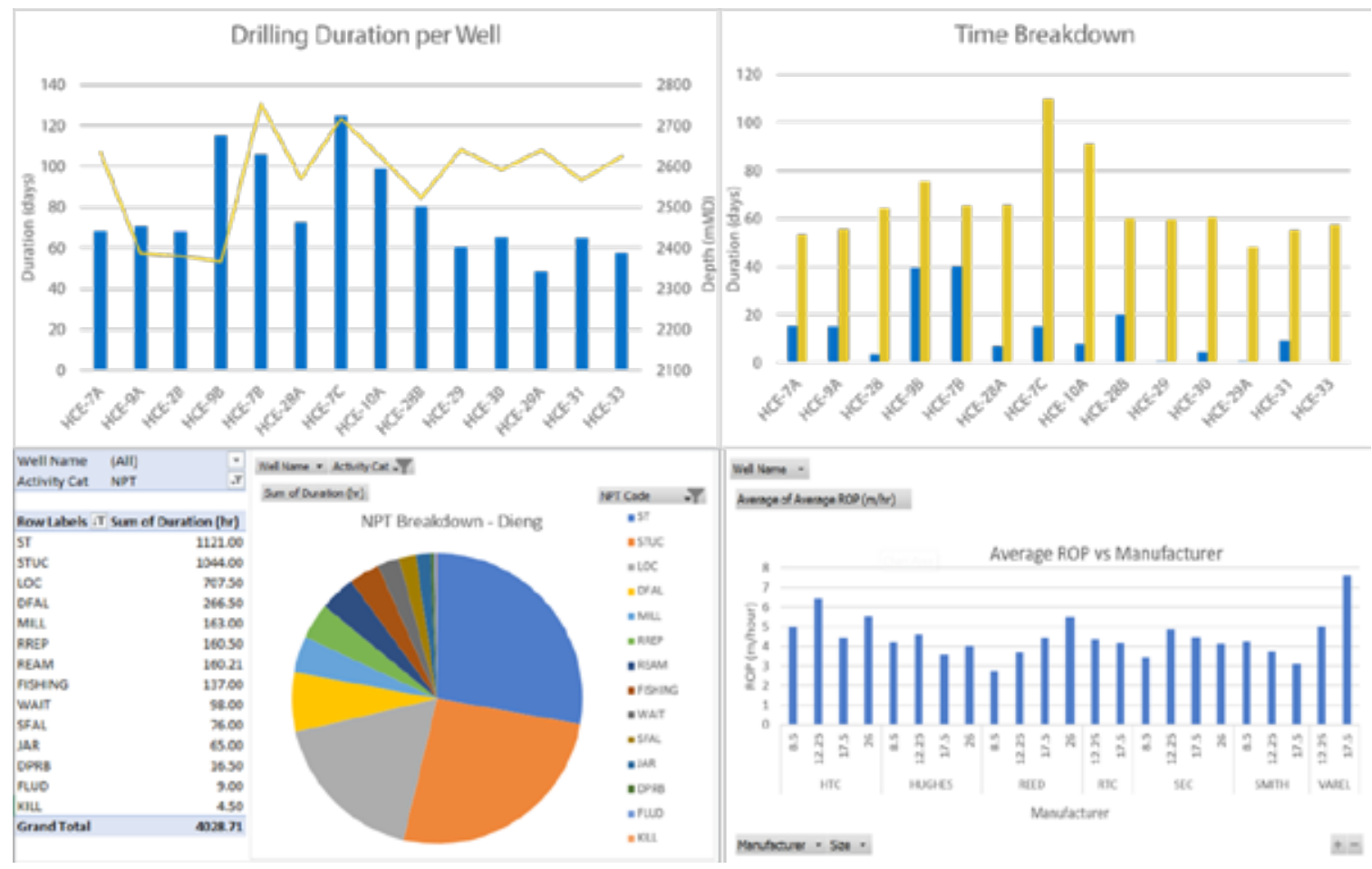

Gambar 14. Beberapa informasi yang dapat diekstraksi setelah proses pembersihan data pada data lama 